\title{
Characterization of Zn-Mg-Al Based Drosses from the Continuous Galvanizing
}

Katarína Blašková, Jarmila Trpčevská, Mária Kuchárová

Faculty of Metallurgy, Technical University in Košice, Letná 9, 04200 Košice. Slovak Republic. E-mail: katarina.blaskova@tuke.sk, jarmila.trpcevska@tuke.sk

The present paper deals with the microstructure characterization of drosses originated during production of a new type of coating called Zinkomag. This coating creates during continuous galvanizing process and it is characterized by addition of $0.8-1.0$ wt. $\% \mathrm{Mg}$ and $0.8-1.0 \mathrm{wt}$. \% $\mathrm{Al}$ in the zinc galvanizing bath. The addition of magnesium in such coatings leads to increasing of hardness, corrosion resistance, and better color adhesion than most common used coatings (GI coatings). In this paper drosses were investigated using AAS, LM, SEM with EDX microanalysis, and XRD.

Keywords: CGL, Zinkomag, Coating, Dross, Structure

\section{Acknowledgements}

This work was supported by a grant from the Slovak National Grant Agency under the VEGA Project 1/0425/14.

\section{References}

[1] ĎURINÍKOVÁ, E., and col. (2011). Phase and structure characteristics of recycled AlZn10Si8Mg cast alloy. Manufacturing Technology, December 2011, Vol. 11, No. 11, p. 11-17, ISSN: 1213-2489.

[2] USSK RESEARCH AND DEVELOPMENT: Comparison of new ZnAlMg coatings with traditional galvanized (GI) coating, U. S. Steel Košice 2013.

[3] Galvanneal - Differences from Galvanize [online]. [cit. 27. 7. 2016]. Available on the internet: http://www.galvinfo.com/ginotes/GalvInfoNote_1_3.pdf

[4] AČSZ - vplyv malých prídavkov horčíka a hliníka v zinkovej tavenine (do $1 \%$ ) na zlepšenie vlastností žiarovo pozinkovaných ocel'ových plechov. Sborník přednášek - 19. Konference žárového zinkování, 2013, hotel Harmony Club Špindleruv Mlýn. ISBN 978-80-9052998-1-6, s. 192

[5] DUTTA, M. and col. (2010). Morphology and properties of hot dip Zn-Mg and Zn-Mg-Al alloy coatings on steel sheet. Surface and Coatings Technology 205 (2010) 2578-2584.

[6] GRABAN, J., and col. (2013). Influence of coatings chemical composition on corrosion resistence of galvanized steel, U. S. Steel, Košice, s. r. o., Metal 2013, Brno, Czech Republic.

[7] PROSEK, T., and col. (2014). Composition of corrosion products formed on Zn-Mg, Zn-Al and Zn-Al-Mg coatings in model atmospheric conditions, Corrosion Science, Volume 86, September 2014, p. 231-238, ISSN: 0010938X.

[8] KANG-CAI YO, and col. (2012). Microstructure of hot-dip galvanized Zn-Al-Mg alloy coatings, Journal of Shanghai Jiaotong University, December 2012, Volume 17, Issue 6, p. 663-667, ISSN: 1007-1172

[9] TRPČEVSKÁ, J., and col. (2012). Microscopical Evaluation of Hard Zinc Refining by Aluminium, Manufacturing Technology, December 2012, Vol. 12, No. 13, p. 264-267, ISSN: 1213-2489.

[10] Weiss, V., and col. (2015). The Use of Colour Metallography and EDS for Identification of Chemical Heterogenity of Selected Aluminium Alloys Copper and Zinc Alloyed, Manufacturing Technology, December 2015, Vol. 15, No. 6, p. 1048-1053, ISSN: 1213-2489.

[11] COMMENDA, C., and col. (2010). Microstructural characterization and quantification of Zn-Al-Mg surface coatings. Materials characterization 65 (2010) 943-951.

[12] NISHIMURA, K., and col. (2000). Highly Corrosion-resistant Zn-Mg- Alloy Galvanized Steel Sheet for Building Construction Materials, Nippon Steel Technical Report, No. 81 January 2000 [online]. [cit. 29. 7. 2016]. Available on the internet: http://www.nssmc.com/en/tech/report/nsc/pdf/8116.pdf 